\title{
Photosystem II breakdown induced by reactive oxygen species in freshly-isolated Symbiodinium from Montipora (Scleractinia; Acroporidae)
}

\author{
J.-T. Wang ${ }^{1, *}$, P.-J. Meng ${ }^{2,3}$, E. Sampayo ${ }^{4}$, S.-L. Tang ${ }^{5}$, C. A. Chen ${ }^{5,6,7}$ \\ ${ }^{1}$ The Graduate Institute of Biotechnology, Tajen University, Pingtung 907, Taiwan \\ ${ }^{2}$ National Museum of Marine Biology and Aquarium, Pingtung 944, Taiwan \\ ${ }^{3}$ Institute of Marine Biodiversity and Evolution, National Dong Hwa University, Checheng, Pingtung 944, Taiwan \\ ${ }^{4}$ Mueller Laboratory, Department of Biology, Pennsylvania State University, Pennsylvania 16802, USA \\ ${ }^{5}$ Biodiversity Research Center, Academia Sinica, Taipei 115, Taiwan \\ ${ }^{6}$ Institute of Oceanography, National Taiwan University, Taipei 108, Taiwan \\ ${ }^{7}$ ARC Centre for Coral Reef Studies, James Cook University, Townsville, Queensland 4810, Australia
}

\begin{abstract}
Freshly-isolated Symbiodinium (FIS) have been used to study cnidarian-alga symbiosis based on the assumption that their physiological performance is comparable to that of the algae in hospite. This assumption was tested with 15 species of scleractinian corals, using pulse-amplitude modulation (PAM) chlorophyll a $\left(\mathrm{chl}\right.$ a) fluorescence to compare maximum quantum yields $\left(F_{\mathrm{v}} / F_{\mathrm{m}}\right)$ of photosystem II (PSII) in Symbiodinium in hospite and after isolation in seawater. FIS from Montipora spp. exhibited rapid and dramatic decreases (by up to $>95 \%$ ) in PSII activity within 30 min of isolation. In contrast, PSII activities of FIS from 8 other coral species decreased by only 5 to $21 \%$ after $>4 \mathrm{~h}$ in seawater. To investigate possible reasons for this variation, the variation in Symbiodinium genetic type (ITS-2 types), transmission modes and several physiological indices were considered. The rapid loss of PSII activity in FIS from Montipora spp. was not correlated with Symbiodinium ITS-2 type, the mode of symbiont transmission, or ionic regulation capability, nor could consistent chemical effects in host extracts be demonstrated. PSII inactivation was correlated with increased levels of reactive oxygen species (ROS), degradation of pigments in peridinin-chl a protein, and chloroplast disruption, indicating that the FIS was under physiological collapse. The specific mechanism(s) causing Montipora-associated Symbiodinium to fail during the isolation methods used here remain unknown. However, these data indicate that care should be taken when using FIS to represent Symbiodinium in hospite, especially when comparing different species of corals.
\end{abstract}

KEY WORDS: Montipora $\cdot$ Symbiodinium $\cdot$ PSII inactivation $\cdot$ ROS $\cdot$ Symbiont transmission mode $\cdot$ Host extract $\cdot$ Cnidarian $\cdot$ Symbiosis

\section{INTRODUCTION}

Symbiodinium spp. are symbiotic dinoflagellates that reside within corals, sea anemones, and many other marine invertebrates (see review in Coffroth \& Santos 2005). These unicellular algae perform intensive interactions with their animal hosts, including nutrient ex- change (Muscatine 1967, 1990, Dubinsky \& Jokiel 1994, Wang \& Douglas 1997, 1998), enhancement of coral calcification (Pearse \& Muscatine 1971, Barnes \& Chalker 1990), responses to stress (Jones et al. 1998, 2008), and habitat selection (Venn et al. 2008). Increasing seawater temperature causes the breakdown of these symbiotic associations (especially in reef-building corals), 
making them an area of special biological interest (Hoegh-Guldberg 1999, Hoegh-Guldberg et al. 2007, Weis 2008, Weis et al. 2008).

Determining the contribution of host and Symbiodinium to the holobiont physiology is problematic without separation of Symbiodinium from the host. Since culturing of Symbiodinium in vitro may not be representative of conditions in hospite, many studies instead use freshly isolated Symbiodinium (FIS) suspended in seawater, which is assumed to be more physiologically similar to Symbiodinium in hospite (Muscatine 1967, Hinde 1988, Sutton \& Hoegh-Guldberg 1990, Wang \& Douglas 1997). However, this assumption is questionable. The intracellular environments of marine invertebrates have lower concentrations of $\mathrm{Na}^{+}$and $\mathrm{Ca}^{2+}$, higher concentrations of $\mathrm{K}^{+}$, and lower $\mathrm{pH}$ than seawater (Kirschner 1991, Goiran et al. 1997). Consequently, changes in these conditions can elicit stress responses, such as a transient $\mathrm{Na}^{+}$shock, as observed in Symbiodinium isolated from the coral Galaxea fasicularis into seawater (Goiran et al. 1997). The process of making FIS could therefore shock Symbiodinium. This effect might be more significant in the corals with vertical transmission of Symbiodinium, because these algae may not encounter seawater environments for many generations, and hence may lose their ability to adapt to changing salinities. Furthermore, the specialized environment of Symbiodinium in hospite, defined by the symbiosome membrane, is lost when symbioses are disrupted, potentially exposing the algae to a variety of novel host-derived enzymes. Even though these enzymes may have minimal affects on some Symbiodinium, which have been documented in many studies by directly using the host tissue extract as 'host factor' to induce photosynthate release from Symbiodinium (Sutton \& Hoegh-Guldberg 1990, Gates et al. 1995, 1999, Wang \& Douglas 1997), they might be significant in other cases. For example, Bhagooli \& Hidaka (2003) observed that Symbiodinium from the coral Montipora digitata lost maximum quantum yield $\left(F_{\mathrm{v}} / F_{\mathrm{m}}\right)$ of photosystem II (PSII) quickly after isolation into seawater, whereas Symbiodinium from 4 other species retained normal PSII function. The ultrastructure of the Symbiodinium from a soft coral Capnella gaboensis was observed to be severely damaged after isolation, which was also assumed to be the effects of host-tissue extracts (Sutton \& HoeghGuldberg 1990).

Since FIS is frequently used in exploring the physiological interactions between cnidarians (e.g. coral) and their symbiotic alga, it is important to clarify these phenomena and determine whether they are general properties of FIS. In the present study, we examined the variation in PSII activity $\left(F_{\mathrm{v}} / F_{\mathrm{m}}\right)$ in Symbiodinium isolated into seawater from 15 species of scleractinian corals for correlations with coral species, Symbiodinium ITS-2 type, the mode of symbiont transmission between host generations (vertical versus horizontal), and the differences in host response to the stress derived from physical disruption. The effects of increased $\mathrm{Na}^{+}$influx, loss of photosynthetic pigment concentration, loss of plastid membrane integrity, and the production of reactive oxygen species (ROS) in the algae were also examined in detail to reveal the possible cause(s) of PSII inhibition in the FIS from some coral hosts.

\section{MATERIALS AND METHODS}

Collection and maintenance of corals. Multiple colonies of 15 species of scleractinian corals (see Table 1 ) were collected from the shallow water $(<5 \mathrm{~m})$ reefs located at the outlet of a nuclear power plant in the Kenting National Park, Taiwan $\left(21^{\circ} 55^{\prime} 54^{\prime \prime} \mathrm{N}\right.$, $120^{\circ} 44^{\prime} 45^{\prime \prime}$ E) between October 2008 and June 2009. The seawater temperature at the sampling site rises to over $30^{\circ} \mathrm{C}$ during mid-summer, which is 1.5 to $2.0^{\circ} \mathrm{C}$ higher than the ambient water in Kenting reefs (Meng et al. 2008). Coral colonies were transferred to the laboratory within $3 \mathrm{~h}$ in an aerated plastic box, and maintained in an aquarium tank $(60 \times 45 \times 45 \mathrm{~cm})$ equipped with illumination $(12 \mathrm{~h}$ light:12 $\mathrm{h}$ dark regime and ca. $50 \mu \mathrm{mol}$ photons $\mathrm{m}^{-2} \mathrm{~s}^{-1}$ photosynthetically active radiation), temperature control $\left(25^{\circ} \mathrm{C}\right)$, filtration (EHEIM), and a protein skimmer. Corals were utilized for experiments within $2 \mathrm{wk}$, even though others remained healthy for at least 1 mo in this aquarium system. Replicate number (n) in the following description indicates the number of coral colonies used.

Isolation of Symbiodinium and fluorescence methodology. Immediately prior to isolating Symbiodinium, maximum quantum yields of PSII $\left(F_{\mathrm{v}} / F_{\mathrm{m}}=\left[F_{\mathrm{m}}-F_{0}\right] / F_{\mathrm{m}}\right)$ of the same Symbiodinium in hospite were determined as follows: coral fragments were transferred to a separate tank covered with a black sheet for darkadaptation for $30 \mathrm{~min}$ at $25^{\circ} \mathrm{C}$ (Ralph 2005), after which minimum $\left(F_{0}\right)$ and maximum $\left(F_{\mathrm{m}}\right)$ fluorescence was measured using a DIVING-PAM fluorometer (Walz) at the DIVING-PAM setting of 8 for measuring-light and a saturating flash of actinic light.

Coral fragments with 5 to $10 \mathrm{~cm}^{2}$ of live tissue were stripped of tissue using a modified air blast technique (Rowan 1991). After mixing with 2 to 3 volumes of $0.45 \mu \mathrm{m}$ filtered seawater (FSW) in a $25 \mathrm{ml}$ syringe, the resultant slurry was passed through $15 \mu \mathrm{m}$ nylon mesh to remove debris. Symbiodinium were then isolated by repeat centrifugation at $860 \times g$ for $3 \mathrm{~min}$ and washed 3 times with FSW (Wang \& Douglas 1997). Since the time required for FIS preparation varied 
between 10 and 20 min, initial measurements of $F_{\mathrm{v}} / F_{\mathrm{m}}$ were made at 30 min following air blasting of coral tissue. One ml of FIS (ca. $10^{5}$ cells ml-1) was suctioned onto $0.45 \mu \mathrm{m}$ membrane filters (Advantec) at the set time. $F_{\mathrm{v}} / F_{\mathrm{m}}$ on $0.45 \mu \mathrm{m}$ membrane filters were measured in a transparent plastic bag immediately after collection, according to the method modified from Bhagooli \& Hidaka (2003). The stability of PSII activity in the FIS was then examined by measuring $F_{\mathrm{v}} / F_{\mathrm{m}}$ repeatedly at 30 or 60 min intervals, for a total of $4 \mathrm{~h}$, during which time the FIS preparations were kept in the dark at $25^{\circ} \mathrm{C}$. In order to avoid anaerobic conditions, the algal suspension was mixed by gently inverting every 10 to $20 \mathrm{~min}$. Measurements of $F_{\mathrm{v}} / F_{\mathrm{m}}$ of FIS were expressed as indices of PSII inactivation $(\%)$ :

PSII inactivation $=\left[\left(F_{\mathrm{v}} / F_{\mathrm{m}}\right)_{\mathrm{C}}-\left(F_{\mathrm{v}} / F_{\mathrm{m}}\right)_{\mathrm{FIS}}\right] /\left(F_{\mathrm{v}} / F_{\mathrm{m}}\right)_{\mathrm{C}} \times 100 \%$

where $\left(F_{\mathrm{v}} / F_{\mathrm{m}}\right)_{\mathrm{C}}$ and $\left(F_{\mathrm{v}} / F_{\mathrm{m}}\right)_{\mathrm{FIS}}$ are the values measured in intact coral and FIS, respectively.

PCR-DGGE analysis of Symbiodinium ITS-2 types. The FIS were preserved in $70 \%$ ethanol at $-20^{\circ} \mathrm{C}$ before DNA extraction with the Viogene Plant Genomic DNA Extraction Miniprep System (Viogene). The Symbiodinium DNA was extracted from ca. $10^{6}$ cells of FIS and suspended in $150 \mu \mathrm{l}$ distilled water, and then used to identify Symbiodinium ITS-2 types as described by LaJeunesse (2002). Briefly, the internal transcribed spacer region 2 of ribosomal DNA (ITS2) was amplified by PCR using the designed primer set ITSintfor2 (5'-AAT TGC AGA ACT CCG TG-3') and ITS2 clamp (5'-CGC CCG CCG CGC CCC GCG CCC GTC CCG CCG CCC CCG CCC GGG ATC CAT ATG CTT AAG TTC AGC GGG T-3'), and products were analyzed by denaturing-gradient gel electrophoresis (DGGE). Diagnostic PCR products were eluted from each gel, reamplified, and sequenced. The final identification of ITS-2 type with sequence data was conducted by E. Sampayo in Dr. LaJeunesse's laboratory at the Mueller Laboratory, Department of Biology, Pennsylvania State University, USA.

Determination of physiological status of isolated Symbiodinium. To reveal cell integrity and physiological condition of the FIS, $\mathrm{Na}^{+}$channel stability (an indicator to show if cells could maintain lower $\mathrm{Na}^{+}$level than external environment), the concentration of photosynthetic related pigment (an indicator representing the photosynthetic integrity within Symbiodinium cells), and of ROS (an indicator representing stress occurring in the cells) in the FIS were examined. According to a method modified from Goiran et al. (1997), FIS used for $\mathrm{Na}^{+}$channel stability were isolated from corals by blasting with $60 \mathrm{mM} \mathrm{Na}^{+}$artificial seawater (ASW, modified from Wang \& Douglas 1997), and washed 3 times by repeat suspension and centrifu- gation $(860 \times g, 3 \mathrm{~min})$ with the same ASW medium to remove host debris. Determination of $\mathrm{Na}^{+}$influx began with suspending these FIS into FSW, followed by collecting $1 \mathrm{ml}$ aliquots (corresponding to about $10^{6}$ cells) at 15 or 30 min intervals for determination of intracellular $\mathrm{Na}^{+}$ion concentration. Then, the FIS suspensions were washed 3 times with $1.2 \mathrm{ml}$ of ice-cold isotonic glycine buffer (glycine 1.1 M, Tris $5 \mathrm{mM}$, pH 8.2) using quick spins $(6120 \times g$ for $7 \mathrm{~s})$ and re-suspension. Total washing procedure was controlled within $3 \mathrm{~min}$. The resulting cell pellet was re-suspended in $1 \mathrm{ml}$ distilled water and disrupted by ultrasonication (Sonics \& Materials) for $5 \mathrm{~min}$ on ice. The concentration of $\mathrm{Na}^{+}$was then determined by atomic absorption spectrophotometry (Hitachi, model Z-5000), and expressed as uequiv $\mathrm{mg}^{-1}$ protein.

Contents of the total chlorophyll a ( $\operatorname{chl} a)$, of peridinin and chl $a$ in peridinin-chl a protein (PCP), and of total soluble protein in the FIS were then determined. Prior to pigment and protein determination, FIS were incubated at $25^{\circ} \mathrm{C}$ under dim light. At 30 min intervals, cells were collected by centrifuging $1 \mathrm{ml}$ aliquots (about $10^{6}$ cells). The samples for PCP and protein determination were extracted with $1 \mathrm{ml} 1 \mathrm{mM}$ Tris- $\mathrm{HCl}$ ( $\mathrm{pH}$ 8.0), and those for total chl a determination were extracted with $1 \mathrm{ml} 90 \%$ acetone. Exact cell numbers in each sample were measured using a Neubauer improved haemocytometer (Marienfeld). Pigments of PCP in the water-soluble fraction were quantified by spectrum analysis using a spectrophotometer (Hitachi U-1900) and expressed as absorbance per $10^{6}$ cells at specific wavelength (459 nm for peridinin; $438 \mathrm{~nm}$ and $673 \mathrm{~nm}$ for $\mathrm{chl}$ a) following the spectrum data obtained by Haxo et al. (1976). Total chl a content in the acetone extract was determined spectrophotometrically using the equation developed by Jeffrey \& Haxo (1968). Protein content was quantified using a protein assay kit (Bio-Rad) according to the manufacturer's instruction for microassay, using bovine serum albumin as the standard.

ROS in FIS were detected by incubating $1 \mathrm{ml}$ of algal suspension with $5 \mu \mathrm{l}$ 2', 7'-dichlorofluorescin diacetate ( $\mathrm{H}_{2}$ DCFDA, $10 \mathrm{mM}$ in dimethylsulfoxide) for $30 \mathrm{~min}$ in the dark, followed by fluorescence microscopy (Mydlarz \& Jacobs 2004). For quantifying ROS, $\mathrm{H}_{2}$ DCFDAtreated FIS were washed twice with FSW, frozen as cell pellets in liquid nitrogen to stop the reaction, and then thawed in $200 \mu \mathrm{l}$ methanol for $10 \mathrm{~min}$. After vortexing and centrifugation at $21500 \times g$ for $5 \min \left(4^{\circ} \mathrm{C}\right)$ to pellet the cells, $20 \mu \mathrm{l}$ of the methanol extract was injected into a fluorescence detector (Hitachi L-2485) for measuring the fluorescence intensity (excitation at $488 \mathrm{~nm}$ and emission at $525 \mathrm{~nm}$ ) (Mydlarz \& Jacobs 2004). The data were expressed in arbitrary fluorescence units per $10^{6}$ cells. 
Transmission electron microscopy (TEM). FIS from Galaxea fasicularis and Montipora aequituberculata were harvested by centrifugation $(3 \mathrm{~min}$ at $860 \times g$ ) immediately after isolation and fixed in cacodylate buffer containing $4 \%$ paraformaldehyde and $8.6 \%$ sucrose for $2 \mathrm{~h}$. Pellets of the algal cells were washed in a series of $0.1 \mathrm{M}$ phosphate buffers with descending sucrose concentration and postfixed in $1 \% \mathrm{OsO}_{4}$ (in $0.1 \mathrm{M}$ phosphate buffer) for $4 \mathrm{~h}$. After dehydration in an ascending acetone series (30 to $100 \%$ ), samples were embedded in Spurr's resin, sectioned $(50 \mathrm{~nm}$ thickness) with a Leica ultramicrotome (EM UC6), stained with $5 \%$ uranyl acetate and $0.5 \%$ lead citrate, and examined with a Phillips CM-100 transmission electron microscope.

Montipora extract and PSII inactivation. To test whether the host tissue slurry from Montipora spp. contained detrimental factors which inactivate the PSII function of Symbiodinium, FIS from Galaxea fasicularis, the most stable FIS found in this study, was incubated with the host extract of $M$. aequituberculata. Various concentrations of host tissue extract (measured with protein concentration) were prepared from air-blasted $M$. aequituberculata tissue and the first run of centrifugation ( $3 \mathrm{~min}$ at $860 \times g$ ). The incubation of FIS from G. fasicularis mimicked the preparation procedure of FIS from $M$. aequituberculata: the FIS was resuspended in Montipora extract for $10 \mathrm{~min}$, and then collected by centrifugation and transferred to fresh FSW for a further $20 \mathrm{~min}$ incubation. $F_{\mathrm{v}} / F_{\mathrm{m}}$ of the treated FIS was then measured (as described in 'Isolation of Symbiodinium and fluorescence methodology').

Statistical analysis. Comparisons between treatments on PSII-inactivation were made using a 1-way analysis of variance (ANOVA) followed by Fisher's least significance difference test, with a significance level of 0.05 . Pair comparison of $\mathrm{Na}^{+}$concentration between samples at each time interval was conducted with Student's $t$-test. The correlation between protein concentration and PSII inhibition was evaluated using the Pearson pair-wise test.

\section{RESULTS}

\section{PSII inactivation in isolated Symbiodinium}

FIS obtained from 15 species of scleractinian corals across 6 genera and 4 families were compared. These coral species represented horizontal and vertical symbiont transmission, and 5 different ITS-2 types of Symbiodinium
(Table 1). Due to the detection limit of DGGE, a Symbiodinium ITS-2 type population less than $10 \%$ is difficult to detect. In this study, therefore, the detectable ITS-2 type of Symbiodinium only represented the dominant population. Overall, PSII function, measured with maximum quantum yield, in Symbiodinium from all coral species examined was as high as previous findings by Bhagooli \& Hidaka (2003) immediately before they were isolated into seawater, in which the values of $F_{\mathrm{v}} / F_{\mathrm{m}}$ ranged from 0.640 to 0.720 in hospite $(\mathrm{n}=123)$.

However, when isolated into seawater, the FIS from most Montipora spp., including $M$. aequituberculata, M. efflorescens, $M$. foliosa, $M$. digitata, and $M$. monasteriata, displayed 81 to $100 \%$ inactivation in PSII activity (Table 1). The FIS from M. gaimardi and M. stellata displayed 62 and $67 \%$ PSII inactivation, respectively. In contrast to Symbiodinium from Montipora spp., inactivation of PSII in FIS from Stylophora pistillata, Pocillopora damicornis, Porites lutea, Galaxea fasicularis, and 4 species of Acropora (A. humilis, A. yongei, A. nana, and $A$. intermedia) was no more than $21 \%$ (Table 1 ). Longer-term inactivation of PSII followed the same trends (Fig. 1). $F_{\mathrm{v}} / F_{\mathrm{m}}$ in FIS from M. gaimardi and $M$. stellata decreased to near 0 at $1 \mathrm{~h}$ and $4 \mathrm{~h}$, respectively, whereas $F_{\mathrm{v}} / F_{\mathrm{m}}$ in FIS from $G$. fasicularis, $P$. damicornis, $A$. yongei, and $P$. lutea remained relatively high $(>0.5)$.

Table 1. Coral species used in the present study and their mode of Symbiodinium transmission between generations (V: vertical; $\mathrm{H}$ : horizontal), dominant Symbiodinium identities (ITS-2 type), number of colonies from which a particular ITS-2 type was identified, and the extent of PSII inactivation in Symbiodinium $30 \mathrm{~min}$ after isolation into seawater. In the coral species with 2 genetic types of Symbiodinium between colonies, ITS-2 type and its corresponding colony number are separately recorded (before and after '/')

\begin{tabular}{|c|c|c|c|c|}
\hline Species & $\begin{array}{l}\text { smission } \\
\text { node }\end{array}$ & $\begin{array}{l}\text { Symbiont } \\
\text { ITS-2 type }\end{array}$ & $\mathrm{n}$ & $\begin{array}{c}\text { PSII } \\
\text { inactivation (\%) }\end{array}$ \\
\hline \multicolumn{5}{|l|}{ Acroporidae } \\
\hline Montipora efflorescens & $\mathrm{V}$ & C15/D1a & $8 / 3$ & $99.9 \pm 0.1$ \\
\hline M. aequituberculata & $\mathrm{V}$ & C15/D1a & $12 / 12$ & $98.7 \pm 3.4$ \\
\hline M. monasteriata & $\mathrm{V}$ & C15 & 3 & $96.8 \pm 5.6$ \\
\hline M. foliosa & $\mathrm{V}$ & C15 & 7 & $95.3 \pm 9.0$ \\
\hline M. digitata & $\mathrm{V}$ & C15 & 10 & $81.0 \pm 20.0$ \\
\hline M. gaimardi & $\mathrm{V}$ & C15 & 3 & $67.3 \pm 28.8$ \\
\hline M. stellata & $\mathrm{V}$ & D1a & 12 & $61.9 \pm 18.7$ \\
\hline Acropora yongei & $\mathrm{H}$ & C3 & 3 & $21.0 \pm 11.2$ \\
\hline A. intermedia & $\mathrm{H}$ & $\mathrm{C} 3 \mathrm{~h}$ & 3 & $14.2 \pm 8.0$ \\
\hline A. nana & $\mathrm{H}$ & C3 & 5 & $10.8 \pm 8.0$ \\
\hline A. humilis & $\mathrm{H}$ & C3 & 9 & $10.8 \pm 7.3$ \\
\hline \multicolumn{5}{|l|}{ Pocilloporidae } \\
\hline Stylophora pistillata & $\mathrm{V}$ & $\mathrm{C} 1$ & 11 & $17.6 \pm 3.6$ \\
\hline Pocillopora damicornis & $\mathrm{V}$ & $\mathrm{C} 1$ & 4 & $12.0 \pm 5.1$ \\
\hline \multicolumn{5}{|l|}{ Poritidae } \\
\hline Porites lutea & $\mathrm{V}$ & C15 & 10 & $16.5 \pm 4.4$ \\
\hline \multicolumn{5}{|l|}{ Oculinidae } \\
\hline Galaxea fasicularis & $\mathrm{H}$ & D1a & 8 & $4.8 \pm 2.5$ \\
\hline
\end{tabular}




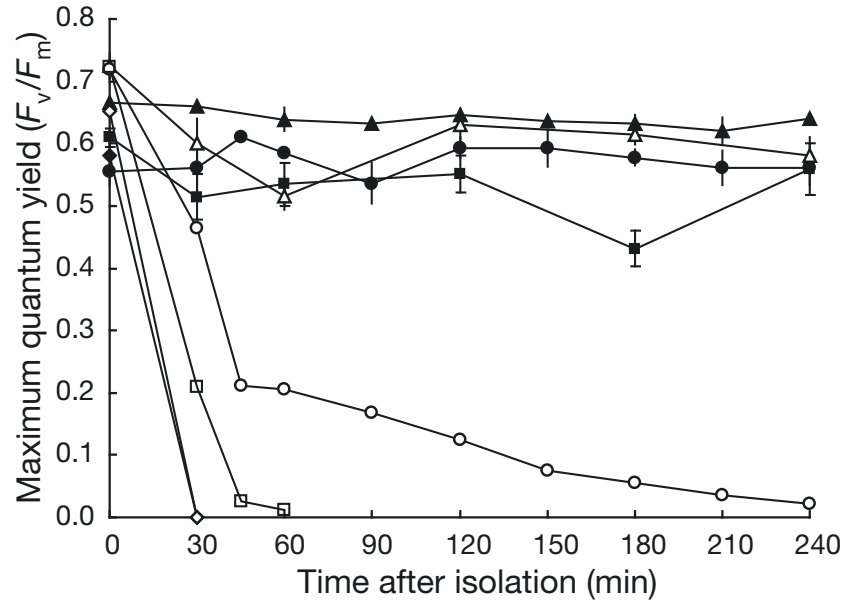

Fig. 1. Changes in maximum quantum yield of PSII $\left(F_{\mathrm{v}} / F_{\mathrm{m}}\right)$ with time in Symbiodinium from different corals after isolation into seawater. The data from hosts Galaxea fasicularis $(\mathbf{\Lambda})(\mathrm{n}=$ 4), Pocillopora damicornis $(\Delta)(\mathrm{n}=4)$, Acropora yongei $(\bullet)(\mathrm{n}=$ $4)$, Porites lutea (घ) $(\mathrm{n}=4)$, Montipora efflorescens $(\bullet)(\mathrm{n}=4)$ and $M$. aequituberculata $(\diamond)(\mathrm{n}=4)$ are means $\pm \mathrm{SD}$, and those from M. stellata $(\mathrm{O})(\mathrm{n}=2)$ and $M$. gaimardi $(\square)(\mathrm{n}=2)$ are means only

Table 1 also indicates that symbiont transmission mode has little bearing on PSII inactivation in FIS. Although Montipora spp. are all vertical transmitters, not all vertical transmitters produced high PSII inactivation in FIS. For example FIS from Stylophora pistillata, Pocillopora damicornis and Porites lutea displayed low PSII inactivation. In addition, the analysis of FIS using PCR-DGGE ITS-2 fingerprints (Fig. 2) and partial 5.8S DNA sequencing (data not shown) showed

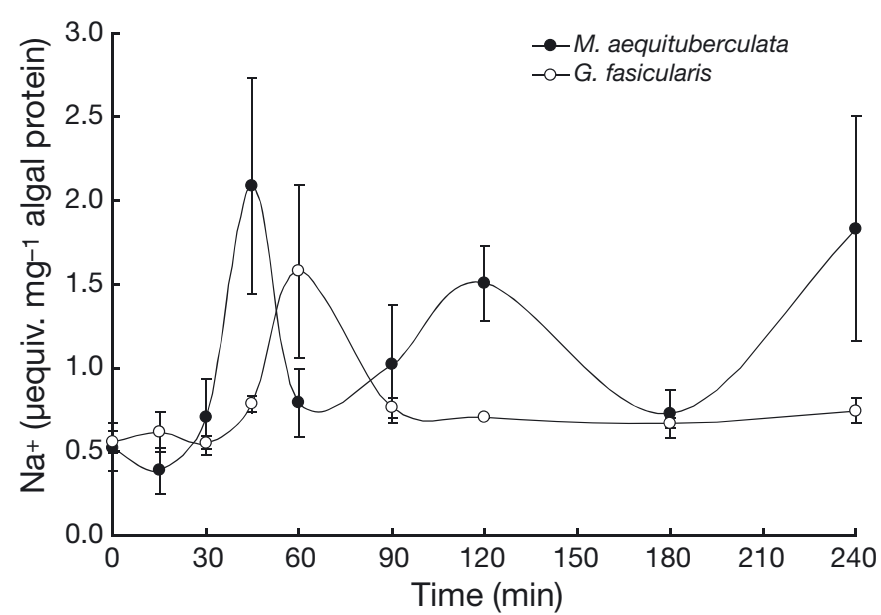

Fig. 3. Intracellular $\mathrm{Na}^{+}$concentrations in Symbiodinium freshly isolated into $60 \mathrm{mM} \mathrm{Na}^{+}$artificial seawater and transferred into filtered seawater at Time 0. Symbiodinium were isolated from Galaxea fasicularis $(\mathrm{O})(\mathrm{n}=6)$ and Montipora aequituberculata $(\bullet)(\mathrm{n}=6)$. Data are mean $\pm \mathrm{SD}$

that Symbiodinium ITS-2 types found in Montipora spp. (D1a, n = 27; and C15, n = 43) could also be found among FIS that did not display high PSII inactivation (D1a, n = 8; and C15, $\mathrm{n}=10$ ) (Table 1).

\section{Cellular events in isolated Symbiodinium}

The fates of FIS cells from Montipora aequituberculata during PSII inactivation were examined using parallel analyses of FIS from Galaxea fasicularis as

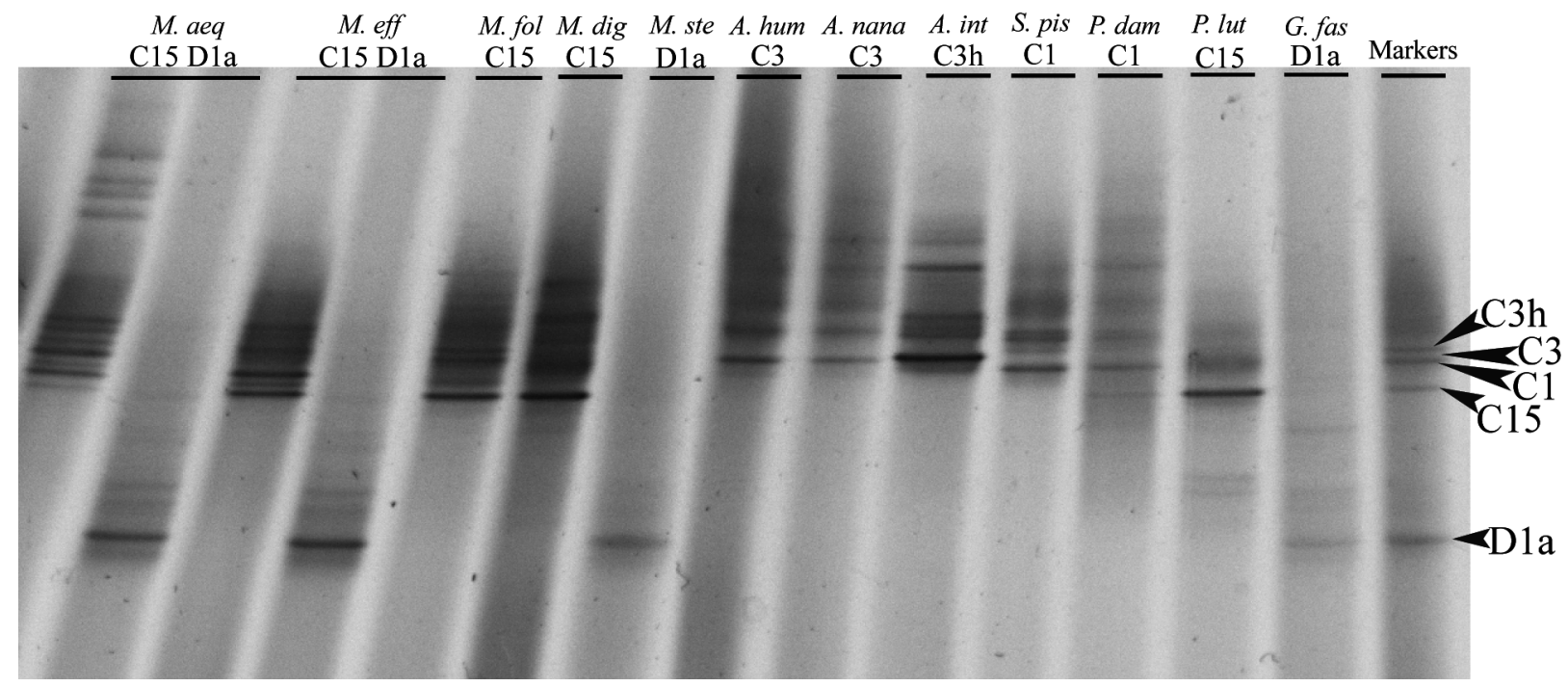

Fig. 2. Representative PCR-DGGE ITS2 fingerprints of Symbiodinium freshly isolated from the corals listed in Table 1 
negative controls. The intracellular $\mathrm{Na}^{+}$pools in these FIS were first compared $(\mathrm{n}=6)$ (Fig. 3). After transfer from $60 \mathrm{mM} \mathrm{Na}^{+}$ASW to FSW, $\mathrm{Na}^{+}$influx was detected at 45 to $60 \mathrm{~min}$ in FIS from G. fasicularis and at 30 to 45 min in FIS from $M$. aequituberculata, with significant 2- to 3-fold increases in intracellular $\mathrm{Na}^{+}$concentration $\left(t_{1,5}=3.920\right.$ and 3.424 for $M$. aequituberculata and G. fasicularis, respectively; $\mathrm{p}<0.05$ ). Influx continued subsequently in both types of FIS, but only the FIS from G. fasicularis maintained intracellular $\left[\mathrm{Na}^{+}\right]$lower than seawater ( 0.67 to 0.76 uequiv $\mathrm{mg}^{-1}$ algal protein) after $4 \mathrm{~h}$.

FIS from Montipora aequituberculata (but not from Galaxea fasicularis) also appeared to become less pigmented during incubation in FSW. When examining the pigments, mean $( \pm \mathrm{SD})$ total chl a contents were similar in FIS from both species $(6.83 \pm 0.35$ and $7.28 \pm$ $0.34 \mu \mathrm{g}$ per $10^{6}$ cells for G. fasicularis and M. aequitu-
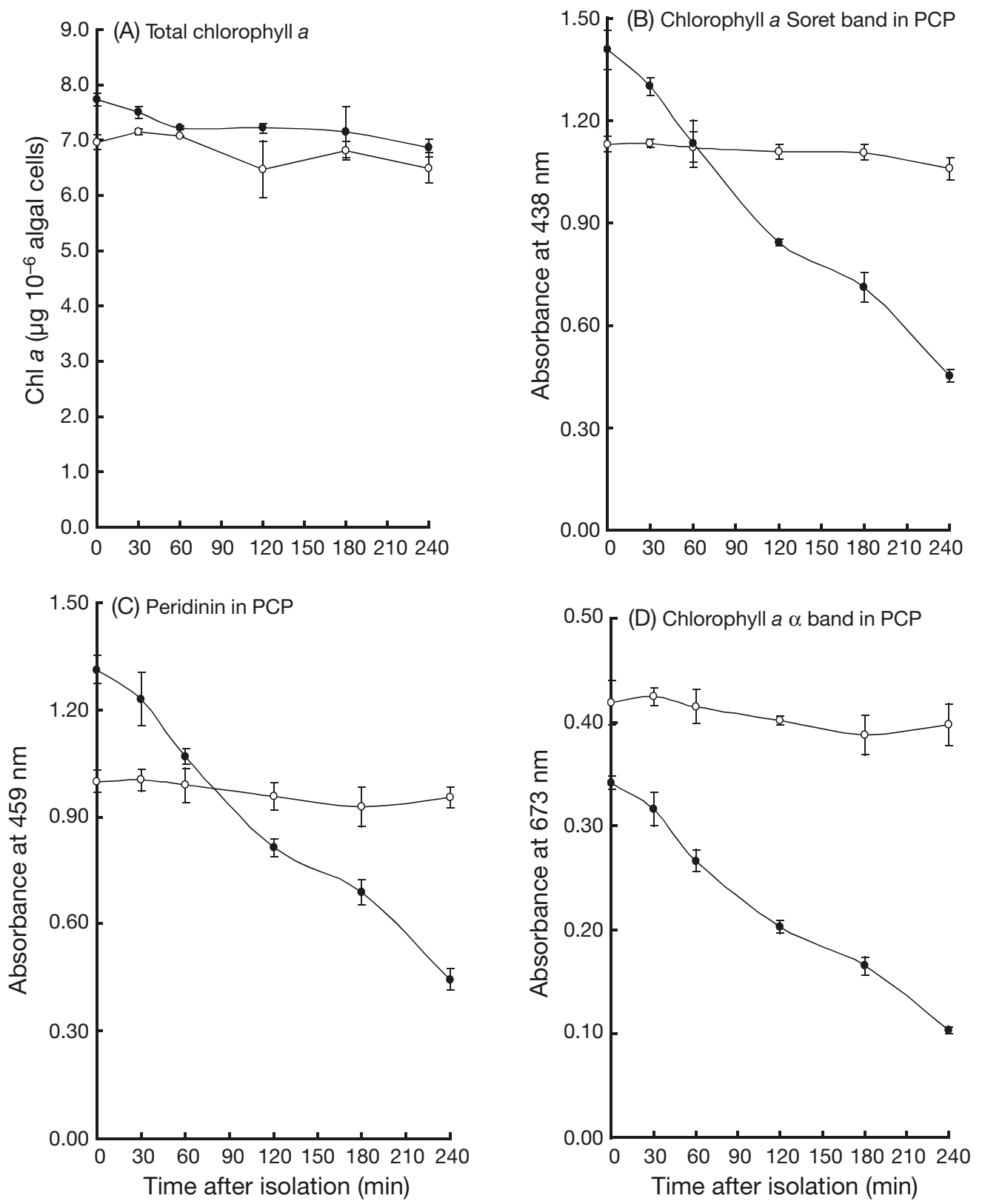

Fig. 4. Contents of photosynthetic pigments in Symbiodinium isolated from Galaxea fasicularis (O) or Montipora aequituberculata (๑) during incubation in filtered seawater. Pigments are (A) total chlorophyll a (chl a) and that in peridinin-chl a protein (PCP) (B) chl a Soret band $(438 \mathrm{~nm}),(C)$ peridinin $(459 \mathrm{~nm})$, and (D) chl a $\alpha$ band per $10^{6}$ Symbiodinium cells. Data are mean \pm SD $(\mathrm{n}=3)$ 

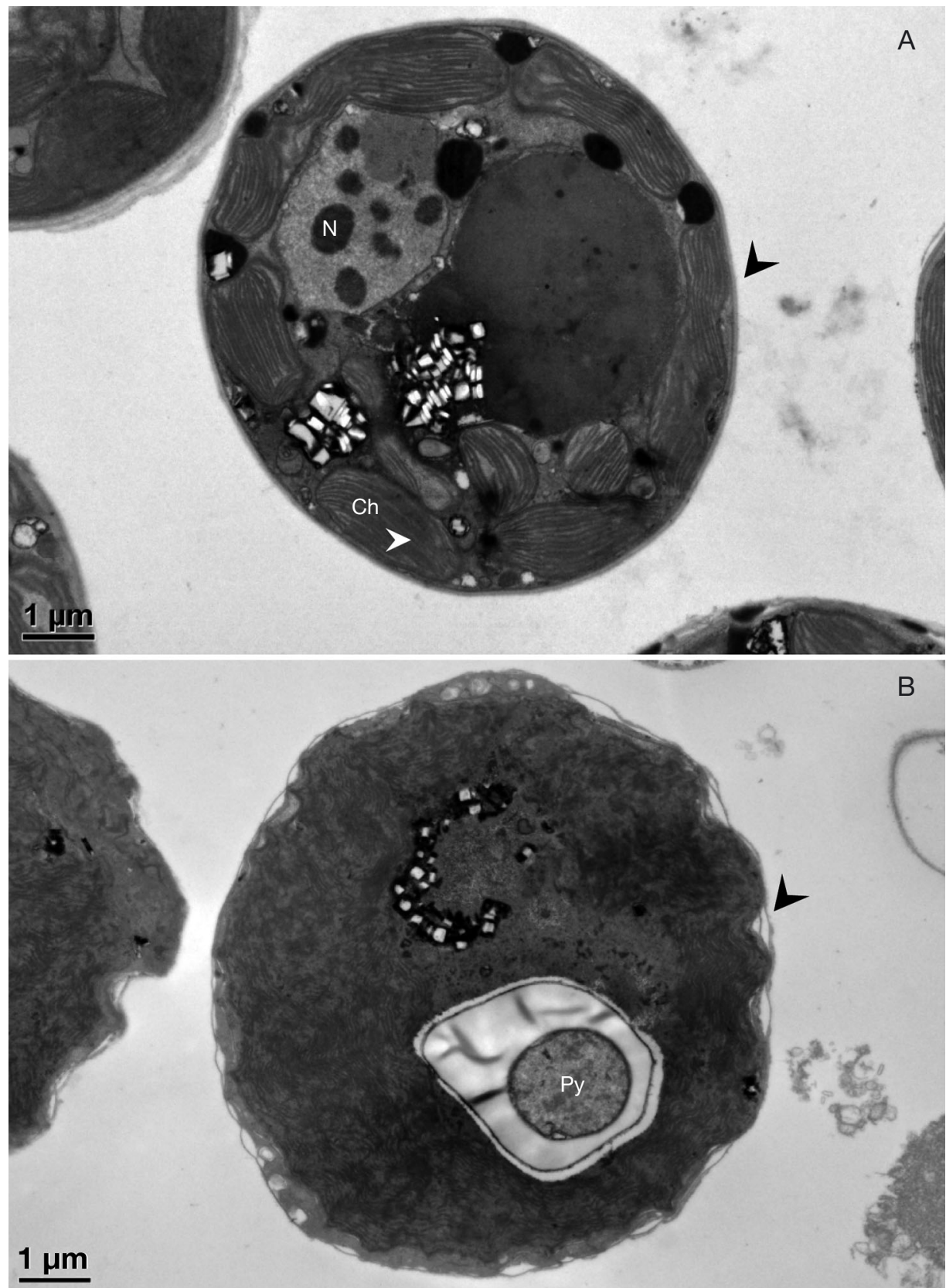

Fig. 5. Transmission electron micrographs of sections of Symbiodinium after isolation in filtered seawater. Algae isolated from (A) Galaxea fasicularis and (B) Montipora aequituberculata. Arrowheads indicate cell wall (black arrow) and plastid membrane (white arrow). Py: pyrenoid; N: nucleus; Ch: chloroplast

berculata, respectively; both $\mathrm{n}=3$ ) during incubation (Fig. 4A). However, only FIS from M. aequituberculata lost PCP pigments (Fig. 4B-D), which displayed $68 \pm 2$, $66 \pm 2$ and $70 \pm 1 \%$ (mean $\pm \mathrm{SD}, \mathrm{n}=3$ ) pigment loss for the chl a Soret band (438 nm), peridinin (459 nm) and chl a $\alpha$ band (673 nm). Moreover, soluble protein in FIS from $M$. aequituberculata decreased by $60 \pm 3 \%$ $($ mean $\pm \mathrm{SD}, \mathrm{n}=3$ ) after $4 \mathrm{~h}$ of incubation, compared to
$19 \pm 2 \%$ (mean $\pm \mathrm{SD}, \mathrm{n}=3$ ) in FIS from G. fasicularis. Further examination of the Symbiodinium ultrastructures using TEM also indicated greater loss of internal cellular integrity in FIS from $M$. aequituberculata, compared to that from G. fasicularis (Fig. 5); the plastid membranes in FIS from $M$. aequituberculata appeared disrupted, whereas plastid structure in FIS from $G$. fasicularis appeared intact. 


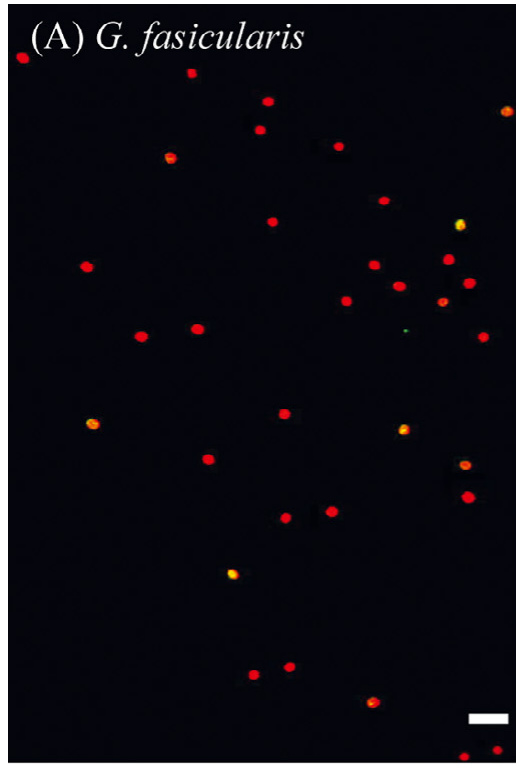

(B) M. aequituberculata

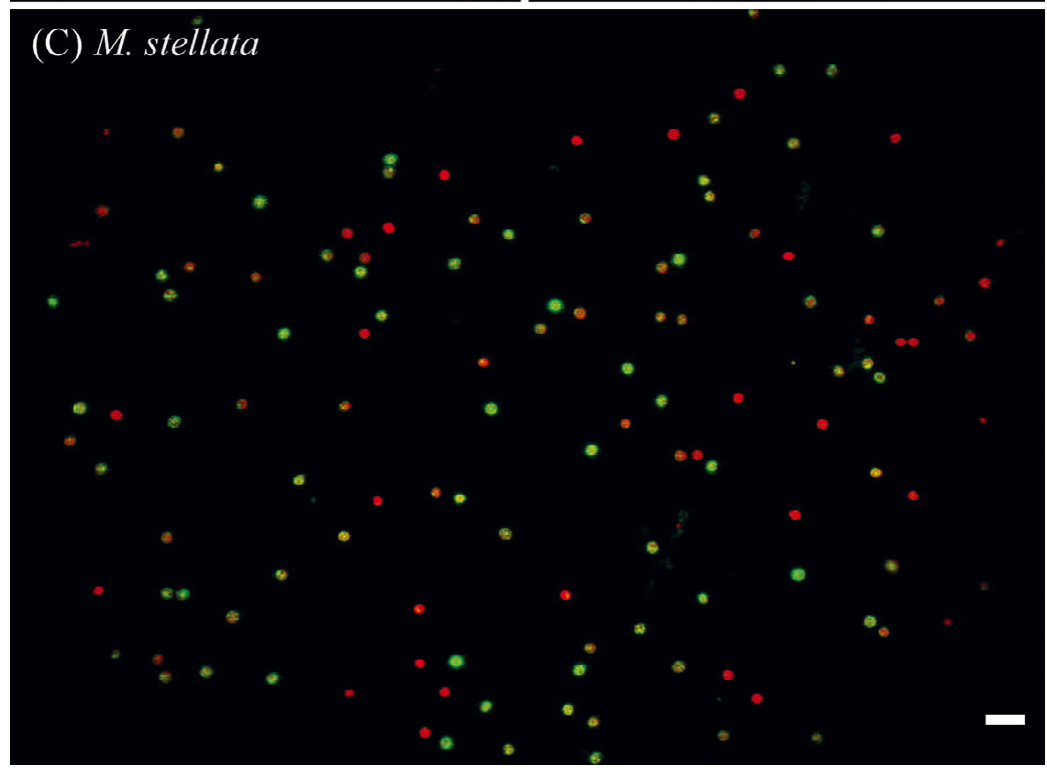

Fig. 6. Reactive oxygen species (ROS) in isolated Symbiodinium detected with the specific indicator $2^{\prime}, 7^{\prime}$-dichlorofluorescein. FIS were obtained from (A) Galaxea fasicularis, (B) Montipora aequituberculata, and (C) Montipora stellata. Green fluorescence is diagnostic of ROS; red is chlorophyll autofluorescence. Scale bars $=50 \mu \mathrm{m}$

Since cellular damage in Symbiodinium associated with coral bleaching is attributed to ROS, the levels of ROS in FIS from Montipora aequituberculata versus Galaxea fasicularis were further compared. In qualitative analyses of FIS incubated for 30 min by fluorescence microscopy, using the probe $\mathrm{H}_{2}$ DCFDA (Fig. 6), a strong ROS signal was observed in highly inactivated FIS from $M$. aequituberculata (Fig. $6 \mathrm{~A}_{i} F_{\mathrm{v}} / F_{\mathrm{m}}<0.100$; green fluorescence); no ROS were observed in FIS from G. fasicularis (Fig. $6 \mathrm{~B}_{;} F_{\mathrm{v}} / F_{\mathrm{m}}=$ 0.624; red autofluorescence of chl a only); and a wide range of ROS signal was seen in moderately inactivated FIS from Montipora stellata (Fig. 6C; $F_{\mathrm{v}} / F_{\mathrm{m}}=0.460 ;$ a mix of green, yellow, and red fluorescent cells). To quantify ROS in FIS, oxidized (fluorescent) DCF was extracted with methanol and measured. The quantitative results indicated that the ROS level displayed significantly positive correlation with PSII inactivation $(\mathrm{r}=0.915, \mathrm{p}<0.001)$ when ROS level was lower than 2.0 fluorescence units $10^{-6}$ cells and reached maximum PSII inactivation $(100 \%)$ at the levels higher than 2.0 (Fig. 7).

\section{Exploration of the cause of PSII inactivation}

The possible effect of host tissue on PSII inactivation was examined by treating FIS from Galaxea fasicularis, as an external control, with host tissue slurries obtained from Montipora aequituberculata. After $30 \mathrm{~min}$ of isolation, PSII inactivation was always high $(>80 \% ; \mathrm{n}=24)$ in the FIS from $M$. aequituberculata, and was always low in FIS from G. fasicularis $(<10 \% ; \mathrm{n}=$ 32). However, when FIS from G. fasicularis were treated with various concentrations of $M$. aequituberculata tissue slurry ( 0.1 to $0.7 \mathrm{mg} \mathrm{ml}^{-1}$ as measured by total soluble protein), the level of PSII inactivation of these samples was variable. Examining from 32 replicates, 8 samples of tissue-slurrytreated FIS from G. fasicularis exhibited $>80 \%$ PSII inactivation, 16 samples exhibited levels from 20 to $80 \%$, and 8 samples exhibited PSII inactivation $<20 \%$. The variation in PSII inactivation between samples was not correlated with the concentration of tissue slurry used $(\mathrm{r}=-0.076, \mathrm{p}>$ $0.05, \mathrm{n}=32$ ).

Some coral-associated bacteria might release enzymes which quickly inactivate the PSII activity of isolated Symbiodinium (Sussman et al. 2009). Therefore, an antibiotic cocktail developed by Polne-Fuller (1991) was supplemented into $250 \mathrm{ml}$ seawater in a crystallization dish to check the retention of PSII function in the 


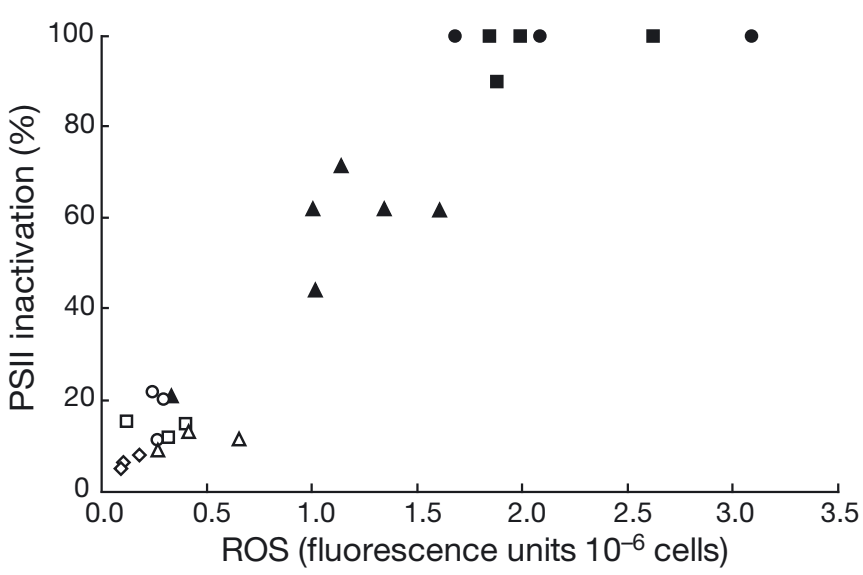

Fig. 7. ROS production and PSII inactivation in isolated Symbiodinium. For these comparisons, Symbiodinium were isolated from Acropora humilis ( $\diamond)$, Porites lutea ( $\square)$, Acropora nana $(\Delta)$, Stylophora pistillata $(O)$, Montipora stellata $(\mathbf{\Lambda}), M$. digitata $(\mathbf{\square})$, and $M$. efflorescens (

FIS from sterile Montipora spp. However, the coral tissue of Montipora aequituberculata disintegrated overnight and left a patch of Symbiodinium on the bottom of the crystallization dish. When Symbiodinium were instead obtained from $M$. aequituberculata via tissue necrosis, using Polne-Fuller's antibiotic cocktail in an overnight procedure, the released algae retained PSII function (mean $\pm \mathrm{SD} F_{\mathrm{v}} / F_{\mathrm{m}}=0.650 \pm 0.021, \mathrm{n}=6$ ).

\section{DISCUSSION}

The data in this study demonstrate that isolating Symbiodinium from corals into seawater, by standard methods, can induce physiological failure such as inactivation of PSII, cell-wall $\mathrm{Na}^{+}$channel dysfunction, ROS production, plastid membrane disruption, and degradation of PCP and protein. Moreover, these effects were coral host species-specific, with FIS from Montipora spp. invariably demonstrating the greatest damage. These findings show that care should be taken when using FIS to study the physiology of coral-Symbiodinium associations, especially when comparing different species of coral.

Previously, loss of PSII activity in FIS from Montipora digitata was suggested to be a consequence of vertical symbiont transmission in Montipora spp. (Bhagooli \& Hidaka 2003). Vertical transmission through oocytes potentially creates lineages of Symbiodinium that never experience seawater environments (but cf. Hirose et al. 2001), and therefore lose the capability to survive outside of hosts. Horizontal transmission, in contrast, implies the existence of freeliving Symbiodinium that must remain adapted to seawater. In this study, however, some corals with vertical symbiont transmission ( $S$. pistillata, Pocillopora damicornis, and Porites lutea) yielded FIS that retained PSII function, implying that sensitivity of FIS to seawater is not an inevitable consequence of vertical symbiont transmission.

In our study, all FIS from Montipora spp. exhibited severe inactivation of PSII, whereas FIS from other coral genera did not (Table 1). This observation suggests that Montipora spp. might harbor a distinct lineage of Symbiodinium that does not tolerate isolation into seawater. Indeed, previous studies of Symbiodinium diversity at other locations implied that Montipora spp. harbor a unique lineage of Symbiodinium (LaJeunesse et al. 2004a,b, van Oppen 2004), identified as ITS-2 type C21 (LaJeunesse et al. 2004b). However, LaJeunesse et al. (2010) reported Symbiodinium ITS-2 type C15 in Montipora spp. in Thailand, which was the predominant ITS-2 type in our Montipora spp. from Taiwan. Additionally, some colonies of $M$. aequituberculata, $M$. efflorescence, and $M$. stellata in our study harbored Symbiodinium ITS-2 type D1a. Both these ITS-2 types (C15 and D1a) are tolerant to high temperatures (LaJeunesse et al. 2003, Fabricius et al. 2004, Fisher 2006), which is consistent with the fact that our corals were collected near the effluent from a power plant $\left(1.5\right.$ to $2^{\circ} \mathrm{C}$ higher than the ambient water in Kenting reefs; Meng et al. 2008). This diversity of Symbiodinium in Montipora spp. argues against the hypothesis of a distinct, seawater-sensitive lineage of Symbiodinium in these corals. Indeed, the ITS-2 type C15 symbionts from Porites lutea and ITS-2 type D1a symbionts from Galaxea fasicularis were observed to be relatively insensitive to isolation in seawater.

Why FIS from only Montipora spp. were so sensitive to isolation in seawater is not known. One possibility is that tissues of Montipora spp. contain inhibitory factors to which Symbiodinium become exposed when the tissues are disrupted. These factors could be host enzymes (Sutton \& Hoegh-Guldberg 1990) or, perhaps, bacteria (Sussman et al. 2009). For example, Sussman et al. (2009) described a zinc metalloprotease produced by coral-pathogenic Vibrio sp. that quickly inactivated PSII of Symbiodinium. For a similar phenomenon to explain our results, the bacterium would have to be specific to Montipora spp., as all of our corals were maintained in the same recirculating aquarium and therefore might all have become infected by a generalist pathogen (Ben-Haim et al. 1999, 2003, Kushmaro et al. 2001, Bally \& Garrabou 2007, Sussman et al. 2008). A bacterial zinc metalloprotease (Sussman et al. 2009) seems an unlikely explanation for our data because neither a protease inhibitor cocktail nor 50 mM EDTA protected FIS from PSII inactivation (data not presented). Also, metalloproteases would be expected to 
act on Symbiodinium cell walls, which were not obviously disrupted when PSII was inactivated and internal plastid membranes were disorganized (Fig. 5B).

Symbiodinium experience dramatic environmental change when isolated from their host, and the physiological failure of FIS from Montipora spp. represents failure to maintain homeostasis under this challenge. For example, FIS isolated into seawater would experience an environmental increase in $\left[\mathrm{Na}^{+}\right]$from $\sim 60 \mathrm{mM}$ to $>500 \mathrm{mM}$ (Goiran et al. 1997). In our experiments, the relatively seawater-insensitive FIS from Galaxea fasicularis partially maintained internal $\mathrm{Na}^{+}$homeostasis, whereas FIS from $M$. aequituberculata did not. It seems unlikely that an uncontrolled $\mathrm{Na}^{+}$shock triggered the physiological failure of FIS from $M$. aequituberculata, because PSII inactivation and ROS production were apparent within 30 min (Table 1, Fig. 6), whereas increased intracellular $\mathrm{Na}^{+}$was apparent only after $1 \mathrm{~h}$ (Fig. 3). Moreover, isolation of FIS from Montipora spp. using ASW with varied $\left[\mathrm{Na}^{+}\right](0$ to $400 \mathrm{mM})$ or $\left[\mathrm{Ca}^{+2}\right](0$ to $9 \mathrm{mM}$ ) did not protect PSII function (data not shown).

Attempts to demonstrate a host-tissue factor that inactivates PSII in FIS were inconclusive. Clearly, tissue slurries from Montipora aequituberculata had some PSII-inhibitory effect on FIS from Galaxea fasicularis, but the effect was inconsistent and there was no evidence of a dose-response relationship. This inconsistency contrasted with the situation for FIS from Montipora spp., in which PSII was always inactivated. This situation requires further study.

One significant linkage of PSII inactivation with FIS from Montipora spp. was ROS production during Symbiodinium isolation by standard methods (Figs. 6 \& 7). However, the PSII inactivation in the FIS from Montipora spp. was completely relieved when the Symbiodinium were isolated by necrosis of coral tissue with an antibiotic cocktail (see 'Results: Exploration of the cause of PSII inactivation'). This antibiotic cocktail had no PSII-protective effect when FIS were isolated from hosts mechanically, by tissue blasting. Thus, it appears that these Symbiodinium can acclimate to seawater, but only when released from their host slowly. Overall, this study suggests that inactivation of FIS from Montipora spp. could be the result of rapid physical disturbance per se, which is known to be associated with ROS bursts in symbiotic or in free-living dinoflagellates (Mydlarz \& Jacobs 2004). Dramatic increase in ROS is a general indicator of stress in plant cells (Lamb \& Dixon 1997), and is also one of the causative agents in cnidarian bleaching (Jones et al. 1998, Downs et al. 2002, Perez \& Weis 2006). ROS may attack almost all intracellular biomolecules, including proteins (Berlett \& Stadtman 1997) and membrane lipids (Tchernov et al. 2004) through oxidation reactions, causing dysfunction of general cell activity. Therefore, the instant PSII inactivation (Fig. 1, Table 1), the $\mathrm{Na}^{+}$ion channel dysfunction (Fig. 3), bleaching of protein-associated pigments (Fig. 4), and plastid membrane disruption (Fig. 5) in the FIS from Montipora spp. likely resulted from the effect of ROS produced during isolation.

In conclusion, we demonstrated that Symbiodinium from Montipora spp. do not tolerate rapid isolation into seawater by commonly used methods, as some Symbiodinium isolated from other species do. The available evidence implies that this is due to some property of the host corals, and not of the Symbiodinium themselves. These findings highlight the importance of host physiology on the physiology of Symbiodinium, and argue that physiological data obtained from FIS should be extrapolated to intact associations with caution, especially when comparing different species of coral.

Acknowledgements. The authors thank Dr. W.-N. Jane for her contribution on TEM examination, H.-W. Tung for her technical support on DGGE, members of Coral Reef Evolutionary Ecology and Genetics (CREEG) Group, Biodiversity Research Centre, Academia Sinica (BRCAS) for field support, Dr. T. C. LaJeunesse for his valuable discussion, and Dr. R. Rowan and $\mathrm{N}$. Rosic for their constructive comments before submission. This work was supported by the Academic Sinica Thematic grant (2008-2010) to J.T.W., S.L.T., and C.A.C., and National Science Council (NSC-96-2628-B-001-004-MY3) to C.A.C. C.A.C. is the recipient of Australian Endevour Award and NSC-Australian Academy of Science fellowship. This is CREEG-BRCAS contribution no. 66.

\section{LITERATURE CITED}

Bally M, Garrabou J (2007) Thermodependent bacterial pathogens and mass mortalities in temperate benthic communities: a new cause of emerging disease linked to climate change. Glob Change Biol 13:2078-2088

Barnes D, Chalker B (1990) Calcification and photosynthesis in reef building corals and algae. In: Dubinsky Z (ed) Ecosystems of the world: coral reefs. Elsevier, Amsterdam, p 109-131

> Ben-Haim Y, Banim E, Kushmaro A, Loya Y, Rosenberg E (1999) Inhibition of photosynthesis and bleaching of zooxanthellae by the coral pathogen Vibrio shiloi. Environ Microbiol 1:223-229

Ben-Haim Y, Thompson FL, Thompson CC, Cnockaert MC, Hoste B, Swings J, Rosenberg E (2003) Vibrio coralliilyticus sp. nov., a temperature-dependent pathogen of the coral Pocillopora damicornis. Int J Syst Evol Microbiol 53: 309-315

> Berlett BS, Stadtman ER (1997) Protein oxidation in aging, disease, and oxidative stress. J Biol Chem 272:20313-20316

Bhagooli R, Hidaka M (2003) Comparison of stress susceptibility of in hospite and isolated zooxanthellae among five coral species. J Exp Mar Biol Ecol 291:181-197

Coffroth MA, Santos SR (2005) Genetic diversity of symbiotic dinoflagellates in the genus Symbiodinium. Protist 156: 19-34

Downs CA, Fauth JE, Halas JC, Dustan P, Bemiss J, Woodley CM (2002) Oxidative stress and seasonal coral bleaching. Free Radic Biol Med 33:533-543 
Dubinsky Z, Jokiel PL (1994) Ratio of energy and nutrient fluxes regulates symbiosis between zooxanthellae and corals. Pac Sci 48:313-324

Fabricius KE, Mieog JC, Colin PL, Idip DH, Van Oppen MJ (2004) Identity and diversity of coral endosymbionts (zooxanthellae) from three Palauan reefs with contrasting bleaching, temperature and shading histories. Mol Ecol 13:2445-2458

Fisher P (2006) Investigating the photo-physiology of Symbiodinium sub-clades and its relationship to coral bleaching. $\mathrm{PhD}$ dissertation, Centre for Marine Studies, University of Queensland, Brisbane

Gates RD, Hoegh-Guldberg O, McFall-Ngai MJ, Bil KY, Muscatine L (1995) Free amino acids exhibit anthozoan 'host factor' activity: they induce the release of photosynthate from symbiotic dinoflagellates in vitro. Proc Natl Acad Sci USA 92:7430-7434

Gates RD, Bil KY, Muscatine L (1999) The influence of an anthozoan 'host factor' on the physiology of a symbiotic dinoflagellates. J Exp Mar Biol Ecol 232:241-259

$>$ Goiran C, Allemand D, Galgani I (1997) Transient $\mathrm{Na}^{+}$stress in symbiotic dinoflagellates after isolation from coral-host cells and subsequent immersion in seawater. Mar Biol 129: 581-589

> Haxo FT, Kycia JH, Somers GF, Bennett A, Siegelman HW (1976) Peridinin-chlorophyll a proteins of dinoflagellate Amphidinium carterae (Plymouth 450). Plant Physiol 57: 297-303

Hinde R (1988) Factors produced by symbiotic marine invertebrates which affect translocation between the symbionts. In: Scannerini S, Smith DC, Bonfante-Fasolo P, Gianinazzi-Pearson V (eds) Cell to cell signals in plant, animal and microbial symbiosis. Springer-Verlag, Berlin, p 311-324

- Hirose M, Kinzie RA, Hidaka M (2001) Timing and process of entry of zooxanthellae into oocytes of hermatypic corals. Coral Reefs 20:273-280

Hoegh-Guldberg O (1999) Climate change, coral bleaching and the future of world's coral reefs. Mar Freshw Res 50: 839-866

> Hoegh-Guldberg O, Mumby PJ, Hooten AJ, Steneck RS and others (2007) Coral reefs under rapid climate change and ocean acidification. Science 318:1737-1742

Jeffrey SW, Haxo FT (1968) photosynthetic pigments of symbiotic dinoflagellates (zooxanthellae) from corals and clams. Biol Bull (Woods Hole) 135:149-165

> Jones RJ, Hoegh-Guldberg O, Larkum AWD, Schreiber U (1998) Temperature-induced bleaching of corals begins with impairment of $\mathrm{CO}_{2}$ fixation mechanism in zooxanthellae. Plant Cell Environ 21:1219-1230

Jones AM, Berkelmans R, van Oppen MJH, Mieog JC, Sinclair W (2008) A community change in the algal endosymbionts of a scleractinian coral following a natural bleaching event: field evidence of acclimatization. Proc Biol Sci 275:1359-1365

Kirschner LB (1991) Water and ions. In: Prosser CL (ed) Comparative animal physiology, 4th edn. Environmental and metabolic animal physiology. Wiley-Liss, New York, NY, p 13-107

Kushmaro A, Banin E, Loya Y, Stackebrandt E, Rosenberg E (2001) Vibrio shiloi sp. nov., the causative agent of bleaching of the coral Oculina paragonica. Int J Syst Evol Microbiol 51:1383-1388

> LaJeunesse TC (2002) Diversity and community structure of symbiotic dinoflagellates from Caribbean coral reefs. Mar Biol 141:387-400

LaJeunesse TC, Loh WK, Woesik RV, Hoegh-Guldberg O,
Schmidt GW, Fitt WK (2003) Low symbiont diversity in southern Great Barrier Reef corals relative to those of the Caribbean. Limnol Oceanogr 48:2046-2054

LaJeunesse TC, Thornhill DJ, Cox EF, Stanton FG, Fitt WK, Schmidt GW (2004a) High diversity and host specificity observed among symbiotic dinoflagellates in reef coral community from Hawaii. Coral Reefs 23:596-603

LaJeunesse TC, Bhagooli R, Hidaka M, deVantier L, Schmidt GW, Fitt WK, Hoegh-Guldberg O (2004b) Closely related Symbiodinium spp. differ in relative dominance in coral reef host communities across environmental, latitudinal and biogeographic gradients. Mar Ecol Prog Ser 284:147-161

> LaJeunesse TC, Pettay DT, Sampayo EM, Phongsuwan N and others (2010) Long-standing environmental conditions, geographic isolation and host-symbiont specificity influence the relative ecological dominance and genetic diversification of coral endosymbionts in the genus Symbiodinium. J Biogeogr 37:785-800

Lamb C, Dixon RA (1997) The oxidative burst in plant disease resistance. Annu Rev Plant Physiol Plant Mol Biol 48: 251-275

Meng PJ, Lee HJ, Wang JT, Chen CC, Lin HJ, Tew KS, Hsieh WJ (2008) A long-term survey on anthropogenic impacts to the water. Environ Pollut 156:67-75

Muscatine L (1967) Glycerol excretion by symbiotic algae from corals and Tridacna and its control by host. Science 156:516-519

Muscatine L (1990) The role of symbiotic algae in carbon and energy flux in reef corals. In: Dubinsky Z (ed) Coral in reefs, Vol 25. Elsevier, Amsterdam, p 75-87

Mydlarz LD, Jacobs RS (2004) Comparison of an inducible oxidative burst in free-living and symbiotic dinoflagellates reveals properties of the pseudopterosins. Phytochem 65: $3231-3241$

Pearse V, Muscatine L (1971) Role of symbiotic algae (zooxanthellae) in coral calcification. Biol Bull (Woods Hole) 141: 350-363

Perez S, Weis V (2006) Nitric oxide and cnidarian bleaching: an eviction notice mediates breakdown of a symbiosis. J Exp Biol 209:2804-2810

Polne-Fuller M (1991) A novel technique for preparation of axenic cultures of Symbiodinium (Pyrrophyta) through selective digestion by amoebae. J Phycol 27:552-554

Ralph P (2005) Introduction to PAM fluorometry. In: HoeghGuldberg $O$ (ed) Understanding the stress response of corals and Symbiodinium in a rapidly changing environment. Proceedings of the Bleaching Working Group Inaugural Workshop, Puerto Morelos, May 10-Jun 3, 2005, p 8-9

Rowan R (1991) Molecular systematics of symbiotic algae. J Phycol 27:661-666

Sussman M, Willis BL, Victor S, Bourne DG (2008) Coral pathogens identified for white syndrome epizootics in the Indo-Pacific. PLoS ONE 3:e2393

Sussman M, Mieog JC, Doyle J, Victor S, Willis BL, Bourne DG (2009) Vibrio zinc-metallopeotease causes photoinactivation of coral endosymbionts and coral tissue lesions. PLoS ONE 4:e4511

Sutton DC, Hoegh-Guldberg O (1990) Host-zooxanthella interactions in four temperate marine invertebrate symbioses: assessment of effect of host extracts on symbionts. Biol Bull (Woods Hole) 178:175-186

- Tchernov D, Gorbunov MY, de Vargas C, Yadav AN, Milligan AJ, Haggblom M, Falkowski PG (2004) Membrane lipids of symbiotic algae are diagnostic of sensitivity to thermal bleaching in corals. Proc Natl Acad Sci USA 101: 13531-13535 
van Oppen MJH (2004) Mode of zooxanthella transmission does not affect zooxanthella diversity in acroporid corals. Mar Biol 144:1-7

> Venn AA, Loram JE, Trapido-Rosenthal HG, Joyce DA, Douglas AE (2008) Importance of time and place: patterns in abundance of Symbiodinium clades A and B in the tropical sea anemone Condylactis gigantean. Biol Bull (Woods Hole) 215:243-252

> Wang JT, Douglas AE (1997) Nutrients, signals, and photosynthate release by symbiotic algae: the impact of taurine on the dinoflagellate alga Symbiodinium from the sea

Editorial responsibility: Peter Edmunds,

Northridge, California, USA anemone Aiptasia pulchella. Plant Physiol 114:213-221

- Wang J, Douglas AE (1998) Nitrogen recycling or nitrogen conservation in an alga-invertebrate symbiosis? J Exp Biol 201:2445-2453

Weis VM (2008) Cellular mechanisms of cndiarian bleaching: stress causes the collapse of symbiosis. J Exp Biol 211: 3059-3066

Weis VM, Davy SK, Hoegh-Guldberg O, Rodriguez-Lanetty M, Pringle JR (2008) Cell biology in model systems as the key to understanding corals. Trends Ecol Evol 23: 369-376

Submitted: June 1, 2010; Accepted: November 1, 2010 Proofs received from author(s): January 14, 2011 